\title{
APLIKASI INSEMINASI BUATAN PADA UDANG WINDU, Penaeus monodon ALAM MENGGUNAKAN SUMBER DAN JUMLAH SPERMATOFOR YANG BERBEDA
}

\author{
Samuel Lante ${ }^{\#}$ dan Asda Laining \\ Balai Penelitian dan Pengembangan Budidaya Air Payau
}

\begin{abstract}
ABSTRAK
Salah satu kendala utama dalam domestikasi udang windu adalah rendahnya tingkat perkawinan secara alami dalam wadah budidaya. Hal yang sama terjadi pada udang windu alam yang digunakan di unit pembenihan. Salah satu upaya untuk mendapatkan telur fertil adalah melalui inseminasi buatan (IB). Inseminasi buatan merupakan teknik mentransfer spermatofor dari induk jantan dengan cara memasukkannya ke dalam telikum udang betina. Penelitian ini bertujuan untuk mengetahui performa reproduksi udang windu betina alam pasca-inseminasi menggunakan sumber dan jumlah spermatofor induk jantan alam yang berbeda. Penelitian dilakukan dua tahap yaitu 1) IB menggunakan spermatofor induk jantan dari perairan Sulawesi Selatan (SS) dan spermatofor induk jantan dari Aceh (SA) dan 2) IB menggunakan jumlah spermatofor berbeda yaitu satu spermatofor (S-1) dan dua spermatofor (S-2) pada udang windu betina alam. Inseminasi spermatofor dilakukan pada induk udang windu betina setelah dua hari moulting. Hasil yang diperoleh pada IB tahap pertama menunjukkan bahwa daya tetas telur udang windu betina alam lokal tidak dipengaruhi oleh sumber (lokasi) asal udang jantan, di mana daya tetas telur relatif sama pada kedua perlakuan, yaitu 61,6\%pada SS dan 61,7\%pada SA. IB pada tahap kedua menunjukkan bahwa daya tetas telur fertil yang diperoleh pada S-2 sebesar 40,5\% lebih rendah dari S-1 sebesar $44 \%$
\end{abstract}

KATA KUNCl: performa reproduksi; inseminasi; spermatofor; udang windu alam

ABSTRACT: Application of artificial insemination for wild tiger shrimp, Penaeus monodon with different sources and numbers of spermatophore. By: Samuel Lante and Asda Laining

\begin{abstract}
One of the main constraints in the domestication of black tiger shrimp is very low natural mating in the tank. Similar condition have been happened in commercial hatcheries. An effort to improve the eggs fertility is through artificial insemination (Al). This study aimed to know reproductive performance of wild black tiger shrimp after insemination with different sources and numbers of spermatophore. This study consisted of two trials. The first one was Al using spermatophores of wild male obtained from two different locations, namely from South Sulawesi (SS) and Aceh (SA). The second trial was Al using different numbers of spermatophore namely one spermatophore (S-1) and two spermatophores (S-2). Al was applied to the females at two days post-moulting. The results of the first trial showed that the hatching rate (HR) was not affected by the source of the male which was $61.6 \%$ for SS and $61.7 \%$ for SA. The second trial indicated that female inseminated S-2 had lower HR than S-1 $(40.5 \%$ vs $44 \%$ ).
\end{abstract}

\section{KEYWORDS: reproductive performances; insemination; spermatophore; wild black tiger shrimp}

\section{PENDAHULUAN}

Indonesia merupakan produsen udang hasil budidaya terbesar ke-4 di dunia pada tahun 2014 dengan komoditas utama udang vaname dan udang windu (World Review SOFIA-FAO, 2014). Sebagai komoditas eskpor, peningkatan produksi udang windu khususnya dari hasil budidaya terus diupayakan, salah satunya adalah dengan penyediaan benih secara

\footnotetext{
\# Korespondensi: Balai Penelitian dan Pengembangan Budidaya Air Payau. J. Makmur Dg. Sitakka No. 129, Maros 90512, Sulawesi Selatan, Indonesia. Tel. + (0411) 371544 E-mail: samuellante98@ yahoo.co.id
}

kontinu baik kuantitas maupun kualitasnya. Udang windu yang dibenihkan di unit pembenihan adalah induk yang berasal dari penangkapan di alam dan diklaim performa reproduksinya menurun seiring dengan meningkatnya frekuensi pemijahannya. Hal ini diindikasikan oleh rendahnya daya tetas telur yang dihasilkan pada rematurasi diduga karena meningkatnya jumlah telur yang tidak fertil atau kualitas telur yang mengalami penurunan. Telur yang tidak fertil pada udang windu dapat disebabkan oleh pembuahan telur yang tidak sempurna atau belum terjadi perkawinan sehingga udang betina tidak 
membawa spermatofor pada telikumnya. Udang windu hasil budidaya telah dilaporkan sulit melakukan perkawinan alami dalam wadah pemeliharaan (Coman et al., 2005; Hoa, 2009, Laining et al., 2014). Induk udang windu yang diperoleh dari alampun diduga mengalami hal yang sama selama proses pematangan gonad dalam bak pemeliharaan khususnya pada proses rematurasi di mana spermatofor yang dibawa dari alam terlepas setelah induk betina moulting.

Salah satu teknik yang dapat diaplikasikan untuk mendapatkan telur fertil pada udang windu adalah melalui inseminasi buatan (IB). Inseminasi buatan merupakan teknik mentransfer spermatofor induk jantan secara buatan dengan cara memasukkan kantong sperma tersebut ke dalam telikum udang betina (Misamore \& Browdy, 1997; Bart et al., 2006). Aplikasi teknik IB telah dilakukan pada beberapa spesies udang di antaranya udang galah, M acrobrachium rosenbergi (Chow, 1982; Claudet et al., 2016), Penaeus setiferus (Misamore \& Browdy, 1997), udang windu, Penaeus monodon hasil budidaya tambak (Lante, 1997), Farfantepenaeus paulensis (Peixoto et al., 2004), udang putih, Litopenaeus vannamei (Arce et al., 2008), dan Penaeus merguiensis (Memon et al., 2012). Penggunaan teknik IB pada induk udang windu hasil domestikasi dalam bak terkontrol dapat menghasilkan daya tetas telur berkisar $81 \% 84 \%$ (Hoa, 2009). Hal yang sama dilaporkan pula pada udang windu hasil budidaya di mana IB dapat meningkatkan fertilitas telur dan menghasilkan larva (Bart et al., 2006; Coman et al., 2007; Arnold et al., 2012).

Kualitas induk udang windu di perairan Indonesia dilaporkan memiliki variasi genetika yang berbeda di mana induk udang yang berasal dari perai ran Aceh dan Sumbawa mempunyai tingkat heterozigositas dan jumlah alel per lokus lebih tinggi dibandingkan dengan induk udang yang berasal dari perairan Jawa Timur dan Sulawesi Selatan (M oria et al., 2002). Berdasarkan informasi ini, maka penggunaan spermatofor dari induk yang berasal dari perairan yang berbeda perlu dilakukan untuk mengetahui pengaruhnya pada keberhasilan inseminasi buatan dalam meningkatkan fertilitas dan daya tetas telur udang windu. Selain itu, induk udang windu yang melakukan kopulasi/kawin secara alami mentransfer dua spermatofor pada telikum udang betina. Aplikasi inseminasi buatan menggunakan jumlah spermatofor yang berbeda masih sangat terbatas pada udang windu.

Penelitian ini bertujuan untuk mengevaluasi teknik inseminasi buatan pada udang windu alam menggunakan sumber dan jumlah spermatofor yang berbeda untuk meningkatkan pembuahan dan daya tetas telurnya.

\section{BAHAN DAN METODE}

\section{Inseminasi Buatan Menggunakan Spermatofor Induk dari Sumber yang Berbeda}

Percobaan pertama ini dirancang dengan dua perlakuan yaitu, IB menggunakan spermatofor dari induk jantan alam yang berasal dari perairan Sulawesi Selatan (SS) dan jantan dari perairan Aceh (SA). Bobot dan panjang udang windu betina dan jantan yang digunakan disajikan pada Tabel 1.

\section{Inseminasi Buatan Menggunakan Spermatofor dengan Jumlah yang Berbeda}

Percobaan kedua adalah inseminasi buatan (IB) menggunakan jumlah spermatofor yang berbeda, yaitu satu spermatofor (S-1) dan dua spermatofor (S-2) dari sumber induk jantan alam perairan Selat Makassar (Sulawesi Selatan) pada induk udang betina alam yang bersumber dari perairan yang sama. Bo bot dan panjang induk udang windu betina alam yang digunakan tertera pada Tabel 2.

Udang windu yang digunakan pada kedua unit percobaan ini adalah hasil tangkapan dari alam yang diangkut ke unit pembenihan dan diadaptasikan dalam bak terkontrol selama dua minggu. Selama proses adapatasi udang windu betina dan jantan diberi pakan segar berupa kombinasi cacing laut, cumi, dan kerang dua kali setiap hari.

\section{Teknik Inseminasi Buatan}

Pada percobaan pertama dan kedua, IB dilakukan dengan teknik yang sama. Tahap pertama dari IB ini adalah mengeluarkan spermatofor induk jantan dengan cara memberikan kejutan elektrik (Sandifer et al., 1984). Kejutan listrik ini dilakukan dengan menggunakan transformer elektrik yang dilengkapi dua elektroda. Kedua elektroda ditempelkan dekat kaki renang ke-5 di bagian bawah badan udang. Dengan adanya kejutan listrik 15 volt/7 mA selama 2-3 detik secara teratur, maka udang jantan mengeluarkan spermatofornya secara perlahan-lahan. Selanjutnya, spermatofor yang dikeluarkan tersebut diambil menggunakan pinset kemudian dimasukkan ke telikum udang windu betina secara berhati-hati. Aplikasi IB ini dilakukan pada induk betina setelah dua hari moulting. Untuk mempercepat pematangan gonad udang windu betina, dilakukan ablasi atau pemotongan tangkai mata.

\section{Kondisi Pemeliharaan Selama Pematangan Gonad Udang Windu}

Pemeliharaan induk selama proses pematangan gonad menggunakan bak beton volume $10 \mathrm{~m}^{3}$ dengan 
Tabel 1. Bobot dan panjang ( \pm SD) induk udang windu alam yang digunakan pada pengamatan IB menggunakan induk jantan dari lokasi yang berbeda

Table 1. Body weight and total length $( \pm S D$ ) of wild broodstock of black tiger shrimp that were used in the observation of artificial insemination using different source of males

\begin{tabular}{lcc}
\hline \multirow{2}{*}{ Variabel Nariables) } & \multicolumn{2}{c}{ Perlakuan (Treatments)* } \\
\cline { 2 - 3 } & SS & SA \\
\hline Jumlah udang betina (ekor) / Number of female (ind.) & 16 & 16 \\
Bobot udang betina (Female body weight) $(\mathrm{g})$ & $100.4 \pm 7.9$ & $110.6 \pm 11.8$ \\
Panjang udang betina (Female total length) $(\mathrm{cm})$ & $21.6 \pm 0.4$ & $22.5 \pm 1.0$ \\
Jumlah udang jantan (ekor) / Number of male (ind.) & 16 & 16 \\
Bobot udang jantan (Male body weight) $(\mathrm{g})$ & $64.4 \pm 7.8$ & $72.8 \pm 10.1$ \\
Panjang udang jantan (Male total length) $(\mathrm{cm})$ & $18.5 \pm 1.9$ & $19.6 \pm 1.1$ \\
\hline *SS $=$ & $\begin{array}{l}\text { induk betina diinseminasi spermatofor jantan Sulawesi Selatan (female } \\
\text { broodstock inseminated with South Sulawesi male spermatophore) }\end{array}$ \\
SA $=$ & $\begin{array}{l}\text { induk betina diinseminasi spermatofor jantan Aceh (female broodstock } \\
\text { inseminated with Aceh male spermatophore) }\end{array}$
\end{tabular}

Tabel 2. Bobot dan panjang ( \pm SD) induk udang windu yang digunakan pada pengamatan IB dengan jumlah spermatofor yang berbeda

Table 2. Body weight and total length ( \pm SD) of wild broodstocks of black tiger shrimp that were used in the observation of artificial insemination using different numbers of spermatophores

\begin{tabular}{|c|c|c|}
\hline \multirow{2}{*}{$\begin{array}{l}\text { Variabel } \\
\text { Variables }\end{array}$} & \multicolumn{2}{|c|}{ Perlakuan (Treatments )* } \\
\hline & S-1 & S-2 \\
\hline Jumlah udang betina (ekor) / Number of female (ind.) & 10 & 10 \\
\hline Bobot udang betina (Female body weight) (g) & $104.7 \pm 12.8$ & $110.4 \pm 10.3$ \\
\hline Panjang udang betina (Female total length ) (cm) & $22.0 \pm 0.9$ & $22.6 \pm 0.8$ \\
\hline Jumlah udang jantan (ekor) / Number of male (ind.) & 10 & 10 \\
\hline Bobot udang jantan (Male body weight) $(\mathrm{g})$ & $64.8 \pm 7.6$ & $63.3 \pm 7.4$ \\
\hline Panjang udang jantan (Male body length) (cm) & $18.4 \pm 1.0$ & $18.6 \pm 1.2$ \\
\hline $\begin{array}{l}\text { induk betina diinseminasi satu spermatofor (f } \\
\text { spermatophore) }\end{array}$ & & ed on \\
\hline $\mathrm{S}-2=\begin{array}{l}\text { induk betina diinseminasi dua spermatofor (fem } \\
\text { spermatophores) }\end{array}$ & & ninated two \\
\hline
\end{tabular}

ketinggian air $60 \mathrm{~cm}$, dengan pergantian air sebanyak $100 \%$ per hari. Induk udang diberi pakan segar berupa kombinasi cacing laut, cumi-cumi, dan kerang sebanyak $15 \%$ dari biomassa udang dengan frekuensi pemberian pakan dua kali per hari yaitu pada pagi dan sore hari.

Parameter yang diamati meliputi: derajat pemijahan, tingkat pembuahan, fekunditas telur, diameter telur, dan daya tetas telur. Derajat pemijahan adalah persentase jumlah induk yang memijah dari jumlah induk yang diinseminasi. Tingkat pembuahan telur adalah persentase jumlah telur yang terbuahi oleh sperma. Fekunditas merupakan jumlah telur yang dihasilkan oleh seekor induk udang windu (Yano et al., 1996), jumlah telur dapat dihitung dengan rumus:

$$
\mathrm{F}=(\mathrm{Vb}: \mathrm{Vg}) \times \mathrm{n}
$$

di mana:

$\mathrm{F}=$ fekunditas (butir telur)

$\mathrm{Vb}=$ volume air di dalam bak pemijahan (L)

$\mathrm{Vg}=$ volume air dalam beaker glass $(\mathrm{mL})$

$\mathrm{n}=$ jumlah telur yang ada di dalam beaker glass (butir)

Data yang diperoleh disajikan dalam bentuk tabel dan gambar, serta dianalisis secara deskriptif. 


\section{HASIL DAN BAHASAN}

\section{Performa Reproduksi Induk Betina Pasca IB dengan Spermatofor dari Sumber Induk yang Berbeda}

Tabel 3 menyajikan keragaan reproduksi induk udang windu betina setelah IB menggunakan spermatofor dari sumber induk yang berbeda. Hasil pengamatan menunjukkan bahwa pada perlakuan SS, dari 16 ekor induk yang diinseminasi, sebanyak tiga ekor induk mengalami kematian. Dari 13 ekor induk betina yang hidup, sebanyak delapan ekor (62\%) yang matang gonad dan dapat memijah. Induk yang tetap membawa spermatofor pada saat memijah sebanyak enam ekor dari delapan ekor yang memijah (75\%). Fekunditas telur yang diperoleh pada perlakuan ini sebanyak 842.760 butir atau rata-rata 105.345 butir/ induk dengan telur fertil 681.860 butir. Total nauplii yang diperoleh dari telur fertil tersebut sebanyak 420.134 ekor atau daya tetas telur sebesar $61,6 \%$ Selanjutnya, diameter telur yang dipijahkan oleh induk udang pada perlakuan SS ini adalah $273,4 \pm 8,6 \mu \mathrm{m}$.

Pada perlakuan SA, jumlah induk betina yang melakukan pemijahan adalah 11 ekor atau 69\%dari 16 ekor induk yang diinseminasi. Semua induk betina yang diinseminasi tetap membawa spermatofor pada saat memijah. Total fekunditas sebanyak 1.965.787 butir dengan rerata 178.708 butir/induk menghasilkan total naupli sebanyak 1.212.495 ekor (110.227 ekor/ induk). Berdasarkan fekunditas telur fertilnya, daya tetas telur sebesar $61,7 \%$ (Tabel 3 ). Rerata diameter telur yang dihasilkan induk pada perlakuan SA adalah 272,6 $\pm 9,7 \mu \mathrm{m}$.

Tingkat pembuahan telur dari jumlah telur yang dihasilkan pasca-inseminasi pada perlakuan SA sebesar

Tabel 3. Performa reproduksi induk betina alam pasca-inseminasi menggunakan spermatofor dari jantan yang berasal dari sumber yang berbeda

Table 3. Reproductive performances of wild female broodstock after inseminated with spermatophores from different sources of male

\begin{tabular}{|c|c|c|}
\hline \multirow{2}{*}{ Variabel (Variables) } & \multicolumn{2}{|c|}{ Perlakuan (Treatments )* } \\
\hline & SS & SA \\
\hline $\begin{array}{l}\text { Jumlah induk betina yang diinseminasi (ekor) } \\
\text { Number of inseminated female (ind.) }\end{array}$ & 16 & 16 \\
\hline $\begin{array}{l}\text { Jumlah induk betina mati (ekor) } \\
\text { Number of dead female broostock (ind.) }\end{array}$ & 3 & 0 \\
\hline $\begin{array}{l}\text { Jumlah induk betina memijah (ekor) } \\
\text { Number of spawned female broodstock (ind.) }\end{array}$ & $8(62 \%)$ & $11(69 \%)$ \\
\hline $\begin{array}{l}\text { Jumlah induk betina membawa spermatofor setelah memijah (ekor) } \\
\text { Number of female broodstock bearing spermatophore after spawn (ind.) }\end{array}$ & $6(75 \%)$ & $11(100 \%)$ \\
\hline $\begin{array}{l}\text { Total fekunditas (butir) } \\
\text { Total fecundity (pcs) }\end{array}$ & $\begin{array}{c}842,760 \\
(\mathrm{n}=8)\end{array}$ & $\begin{array}{l}1,965,787 \\
(n=11)\end{array}$ \\
\hline $\begin{array}{l}\text { Diameter telur } \\
\text { Egg diameter }(\mu \mathrm{m})\end{array}$ & $\begin{array}{l}681,860 \\
(n=6)\end{array}$ & $\begin{array}{r}1,965,787 \\
(n=11)\end{array}$ \\
\hline $\begin{array}{l}\text { Total telur fertil (butir) } \\
\text { Total of eggs fertile (pcs) }\end{array}$ & $\begin{array}{c}420,134 \\
(n=6)\end{array}$ & $\begin{array}{c}1,212,495 \\
(\mathrm{n}=11)\end{array}$ \\
\hline $\begin{array}{l}\text { Jumlah total naupli (ekor) } \\
\text { Total nauplii (ind.) }\end{array}$ & $\begin{array}{c}49.9 \\
(n=8)\end{array}$ & $\begin{array}{c}61.7 \\
(n=11)\end{array}$ \\
\hline \multicolumn{3}{|l|}{$\begin{array}{l}\text { Daya tetas dari total telur } \\
\text { Hatching rate of total eggs (\%) }\end{array}$} \\
\hline $\begin{array}{l}\text { Daya tetas telur fertil } \\
\text { Hatching rate of fertile eggs (\%) }\end{array}$ & $\begin{array}{c}61.6 \\
(n=6)\end{array}$ & $\begin{array}{c}61.7 \\
(\mathrm{n}=11)\end{array}$ \\
\hline
\end{tabular}


$100 \%$ atau semua induk yang memijah pada perlakuan ini menghasilkan telur yang dapat menetas dengan daya tetas dari total telur yang dipijahkan sebesar $61,7 \%$ (Tabel 3). Nilai ini lebih tinggi jika dibandingkan dengan perlakuan SS yang tingkat pembuahannya sebesar $75 \%$ dan daya tetas dari total telurnya sebesar 49,9\% Tingginya tingkat pembuahan telur pada induk betina pasca-inseminasi pada perlakuan SA disebabkan oleh tidak adanya spermatofor yang terlepas dari telikum sejak IB dilakukan hingga induk memijah. Pada perlakuan SS, dari delapan ekor betina yang memijah, enam ekor induk yang membawa spermatofor dan mampu membuahi telurnya, sedangkan dua ekor induk yang lain telurnya infertil diduga karena spermatofor yang diinseminasikan lepas dari telikum sehingga proses pembuahan tidak terjadi. Apabila daya tetas telur dihitung berdasarkan total telur fertil, maka kedua perlakuan menghasilkan daya tetas yang relatif sama yaitu 61,6\%pada SS dan 61,7\%pada SA (Tabel 3).

Tingkat pembuahan telur yang lebih tinggi pada perlakuan SA dibandingkan dengan perlakuan SS (Gambar 1) secara langsung memengaruhi total nauplii yang dihasilkan pada kedua perlakuan di mana kelompok SA menghasilkan nauplii lebih banyak daripada perlakuan SS. Meskipun tingkat pembuahan telur dari jumlah telur yang dihasilkan pasca-inseminasi pada kedua perlakuan relatif berbeda, namun tingkat penetasan telur pada kedua perlakuan relatif sama (Gambar 2). Hal ini menunjukkan bahwa keberhasilan IB pada induk betina alam tidak dipengaruhi oleh sumber spermatofor yang digunakan apakah berasal dari perairan Aceh atau Sulawesi Selatan. Kualitas spermatofor yang digunakan untuk IB pada percobaan ini tidak diamati, tetapi dari hasil pengamatan sebelumnya diketahui bahwa induk udang jantan Aceh rerata jumlah spermanya sebanyak $280.125 \times 10^{3}$ sel/ induk lebih tinggi daripada jumlah sperma dalam spermatofor induk udang jantan Sulawesi Selatan, baik dari Takalar maupun Polman masing-masing 196.263 x $10^{3}$ sel/induk dan $159.438 \times 10^{3}$ sel/induk (Lante et al., 2014). Meskipun jumlah sel sperma induk jantan Aceh lebih banyak, namun sperma normal dan viabilitasnya relatif sama dengan sel sperma jantan dari perairan Sulawesi Selatan sehingga memberikan daya tetas relatif sama pada perlakuan SA dan SS setelah IB dilakukan.

Tingkat penetasan telur pasca-inseminasi pada beberapajenis udang seperti Farfantepenaeus paulensis (Peixoto et al., 2004), udang putih, Litopenaeus vannamei (Arce et al., 2008) dan Penaeus merguiensis (Memon et al., 2012) adalah bervariasi. Penggunaan teknik IB pada induk udang windu hasil domestikasi dalam bak terkontrol dapat menghasilkan daya tetas telur berkisar $81 \% 84 \%(\mathrm{Hoa}, 2009)$. Pada penelitian menggunakan sumber spermatofor induk jantan dari sumber berbeda diperoleh tingkat penetasan telur baik pada SA maupun SS lebih tinggi (sekitar 62\%) dibandingkan IB yang dilakukan pada induk udang windu hasil budidaya (Laining et al., 2014) bahkan lebih tinggi dari tingkat penetasan telur udang windu alam

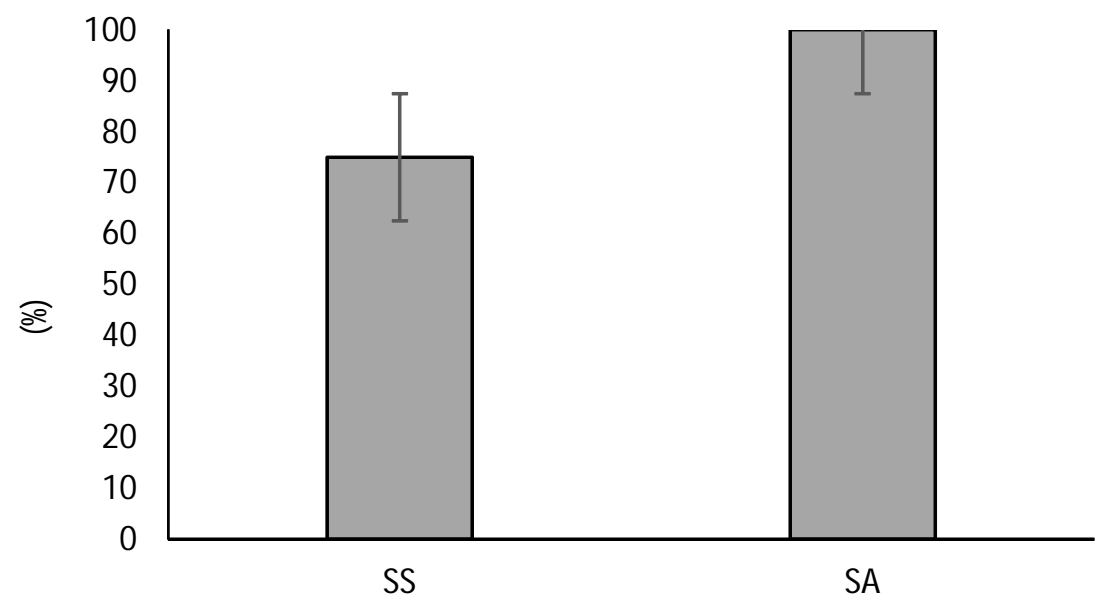

Gambar 1. Tingkat pembuahan telur udang windu pasca-inseminasi dengan spermatofor yang berasal dari sumber induk yang berbeda, SS= spermatofor dari induk Sulawesi Selatan dan SA= spermatofor dari induk Aceh

Figure 1. Fertilization rate of eggs produced after inseminated with spermatophores from different sources of male, SS= spermatophores from South Sulawesi waters and $S A=$ spermatophores from Aceh waters 


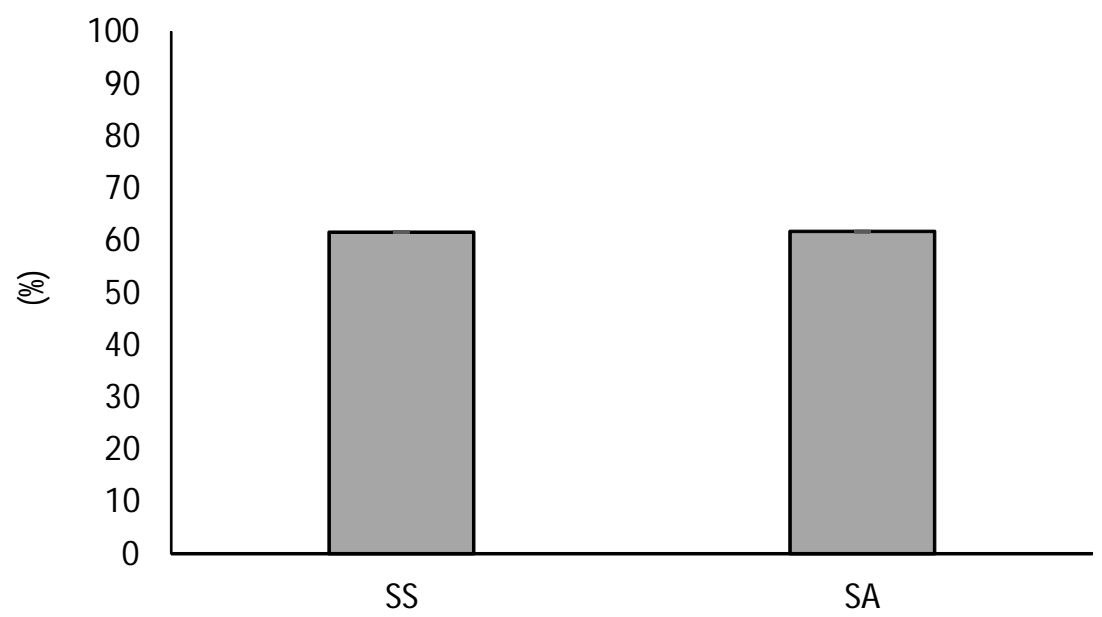

Gambar 2. Tingkat penetasan telur yang dihasilkan oleh induk betina pascainseminasi spermatofor jantan alam yang berasal dari sumber yang berbeda, SS= spermatofor jantan dari perairan Sulawesi Selatan dan $\mathrm{SA}=$ spermatofor jantan dari perairan Aceh

Figure 2. Hatching rate of fertiled eggs produced by female broodstock after inseminated with spermatophores from different sources of male, SS= spermatophore from South Sulawesi waters and $S A=$ spermatophore from Aceh waters

yang kawin secara alami dan diablasi yaitu sekitar $52 \%$ (Laining et al., 2015). Namun Bart et al. (2006) melaporkan bahwa tingkat penetasan telur udang windu pasca-inseminasi dengan spermatofor segar dapat mencapai $88,8 \%$ relatif sama dengan perkawinan alami yaitu $88,3 \%$ maupun IB dengan kryopreservasi spermatofor yaitu 87,8\% Perbedaan tingkat penetasan telur ini kemungkinan salah satu penyebabnya adalah mutu spermatozoa induk jantan yang berbeda pada saat IB dilakukan.

\section{Performa Reproduksi Induk Betina Pasca IB dengan Jumlah Spermatofor yang Berbeda}

Hasil pengamatan pada percobaan ke-2 yaitu IB menggunakan jumlah spermatofor yang berbeda disajikan pada Tabel 4. Persentase induk betina yang memijah pada perlakuan S-1 adalah 80\%atau sebanyak delapan ekor dari 10 ekor induk betina yang diinseminasi, sedangkan pada perlakuan S-2 yang memijah sebanyak $100 \%$ atau semua induk yang diinseminasi dapat memijah. Jumlah telur yang dihasilkan pada perlakuan S-1 sebanyak 1.163.363 butir atau rata-rata 145.420 butir/induk, sedangkan perlakuan S-2 adalah 1.956 .644 butir dengan rerata fekunditas sebanyak 195.664 butir/induk. Fekunditas telur lebih tinggi pada induk betina pada perlakuan S-2 disebabkan bobot induk yang digunakan relatif lebih besar pada perlakuan S-2 dibandingkan pada perlakuan S-1 (Tabel 2), sama halnya dengan perbedaan fekunditas induk yang digunakan pada percobaan ke-
1 di mana induk yang bobotnya lebih besar memiliki fekunditas yang lebih tinggi. Secara umum, rerata fekunditas induk betina yang diamati pada kedua percobaan ini berada pada kisaran jumlah telur induk betina udang windu yaitu 86.000-535.000 telur (Arnold et al., 2012).

Tingkat pembuahan telur pada perlakuan S-1 mencapai 100\% lebih tinggi dari S-2 yaitu 70\%(Gambar 3). Tingginya tingkat pembuahan telur pada induk betina S-1 menunjukkan bahwa IB dengan satu spermatofor penempatannya dalam telikum dapat lebih sempurna dibandingkan jika IB menggunakan dua spermatofor. Diperolehnya $100 \%$ telur fertil pada perlakuan IB menggunakan S-1 mengindikasikan bahwa spermatofor yang diinseminasikan bertahan dalam telikum sehingga dapat digunakan untuk membuahi telur yang dipijahkan oleh udang windu betina. Sebaliknya hanya $70 \%$ telur fertil terjadi pada IB dengan dua spermatofor, hal ini diduga karena posisi dua spermatofor dalam telikum tidak sebaik dengan satu spermatofor sehingga sebagian spermatofor yang telah diinseminasikan keluar dari telikum udang betina sebelum digunakan untuk membuahi telurnya.

Total nauplii yang dihasilkan induk betina pada S-2 relatif lebih banyak dari total nauplii yang dihasilkan pada S-1. Namun demikian tingkat penetasan telur pada S-2 relatif lebih rendah $(40,5 \%)$ daripada S-1 (44\%) (Gambar 4). Tingkat penetasan yang diperoleh pada percobaan pertama (SA dan SS) yang inseminasinya 
Tabel 4. Performa reproduksi udang windu betina alam pasca-inseminasi menggunakan jumlah spermatofor yang berbeda

Table 4. Reproductive performances of wild female broodstock after inseminated with different number of spermatophore

\begin{tabular}{|c|c|c|}
\hline \multirow{2}{*}{ Variabel (Nariables) } & \multicolumn{2}{|c|}{ Perlakuan (Treatments) } \\
\hline & S-1 & S-2 \\
\hline $\begin{array}{l}\text { Jumlah induk betina (ekor) } \\
\text { Number of female broodstock (ind.) }\end{array}$ & 10 & 10 \\
\hline $\begin{array}{l}\text { Jumlah induk betina memijah (ekor) } \\
\text { Number of spawned female broodstock (ind.) }\end{array}$ & 8 & 10 \\
\hline $\begin{array}{l}\text { Jumlah induk betina yang membawa spermatofor (ekor) } \\
\text { Number of female broodstock bearing spermatophore (ind.) }\end{array}$ & $8(100 \%)$ & $7(70 \%)$ \\
\hline $\begin{array}{l}\text { Jumlah telur (butir) } \\
\text { Total of eggs (pcs) }\end{array}$ & $\begin{array}{l}1,163,363 \\
(n=8)\end{array}$ & $\begin{array}{c}1,956,644 \\
(n=10)\end{array}$ \\
\hline $\begin{array}{l}\text { Total telur fertil (butir) } \\
\text { Total of eggs fertile (pcs) spermatophore (ind.) }\end{array}$ & $\begin{array}{l}1,163,363 \\
(\mathrm{n}=8)\end{array}$ & $\begin{array}{l}1,440,090 \\
(\mathrm{n}=7)\end{array}$ \\
\hline $\begin{array}{l}\text { Diameter telur } \\
\text { Eqg diameter }(\mu \mathrm{m})\end{array}$ & $\begin{array}{l}268.8 \pm 1.5 \\
(n=80)\end{array}$ & $\begin{array}{c}273.5 \pm 3.5 \\
(\mathrm{n}=100)\end{array}$ \\
\hline $\begin{array}{l}\text { Jumlah naupli (ekor) } \\
\text { Total nauplii (ind.) }\end{array}$ & $\begin{array}{c}511,916 \\
(\mathrm{n}=8)\end{array}$ & $\begin{array}{l}582,845 \\
(\mathrm{n}=7)\end{array}$ \\
\hline $\begin{array}{l}\text { Daya tetas telur dari total telur } \\
\text { Hatching rate of egg }(\%)\end{array}$ & 44 & 29.8 \\
\hline $\begin{array}{l}\text { Daya tetas telur fertil } \\
\text { Hatching rate of egg fertile }(\%)\end{array}$ & 44 & 40.5 \\
\hline $\begin{array}{l}\mathrm{S}-1=\quad \text { induk betina diinseminasi dengan satu spermatofor } \\
\text { with one spermatophore) } \\
\mathrm{S}-2=\quad \text { induk betina diinseminasi dengan dua spermatofor ( }\end{array}$ & nale broodsto & $\begin{array}{l}\text { was inseminate } \\
\text { vas inseminated }\end{array}$ \\
\hline
\end{tabular}

juga menggunakan satu spermatofor adalah berkisar 49,9\%61,7\%(Tabel 3) lebih tinggi dibandingkan pada perlakuan S-1 pada percobaan kedua. Perbedaan ini diduga terjadi karena perbedaan karakteristik sperma yang terdapat dalam spermatofor yang digunakan pada kedua percobaan tersebut. Spermatozoa yang baik dapat meningkatkan pembuahan telur dan akhirnya meningkatkan daya tetas telur udang.

Salah satu organ reproduksi yang khas pada udang penaied termasuk udang windu adalah spermatofor yang terbentuk di terminal ampul. Spermatofor merupakan kantong berisi sperma yang sudah matang. Menurut Joseph \& Diwan (2009), spermatofor tidak hanya berfungsi sebagai alat transportasi sperma dari induk jantan ke induk betina, tetapi juga sebagai lapisan pelindung sperma selama proses transfer dan penyimpanan dalam telikum udang. Proses perkembangan dan struktur pembentuk spermatofor ini sangat penting diketahui untuk memudahkan proses memanipulasi gametnya sebagai bagian dari upaya aplikasi bioteknologi pada produksi benih udang windu. Jiang et al. (2009) melaporkan bahwa formasi spermatofor dipengaruhi oleh umur dan ukuran, serta kondisi lingkungan di mana udang jantan dipelihara. Hal yang sama dikemukakan oleh Hoang et al. (2002) pada P. merguiensis, tetapi pengamatan mereka menunjukkan bahwa pada udang penaeid ini, kematangan seksualnya lebih dipengaruhi oleh ukuran dibandingkan umur.

Selain kualitas sperma, perbedaan daya tetas telur yang dihasilkan pada beberapa penelitian juga diduga dipengaruhi oleh kualitas telur yang dipijahkan oleh induk betina. Coman \& Crocos (2003) menyatakan bahwa daya tetas telur yang baik ditentukan oleh kondisi lingkungan pemeliharaan, keberhasilan pembuahan, mutu sperma, dan mutu telur. Faktor yang berpengaruh langsung pada performa reproduksi udang windu termasuk mutu spermatofor adalah nutrisi (Wouters et al., 2002; Coman et al., 2007; Hoa, 2009) dan lingkungan (Perez-Velazquez et al., 2001; Jiang et al., 2009; Mylonas et al., 2010).

Meskipun evaluasi secara spesifik mengenai kual itas sperma dan telur yang dihasilkan pada masing- 


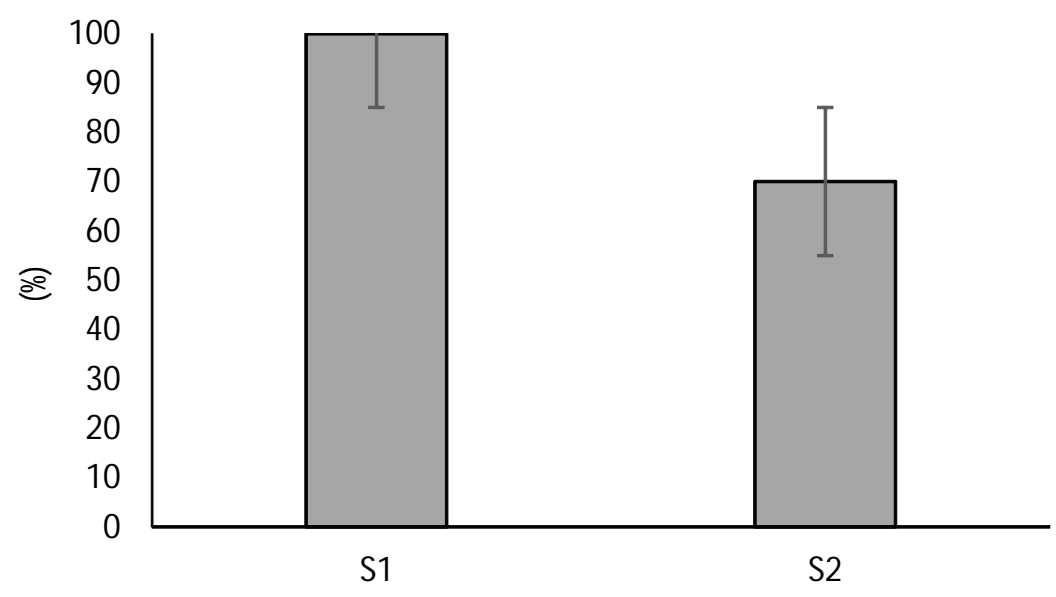

Gambar 3. Tingkat pembuahan telur pasca-inseminasi menggunakan jumlah spermatofor yang berbeda, S-1 = inseminasi dengan satu spermatofor; $\mathrm{S}-2=$ inseminasi dengan dua spermatofor

Figure 3. Fertilization rate of eggs spawned by wild female broodstock after inseminated with different numbes of spermatophore, $\mathrm{S}-1=$ inseminated with one spermatophore; $\mathrm{S}-2=$ inseminated with two spermatophores

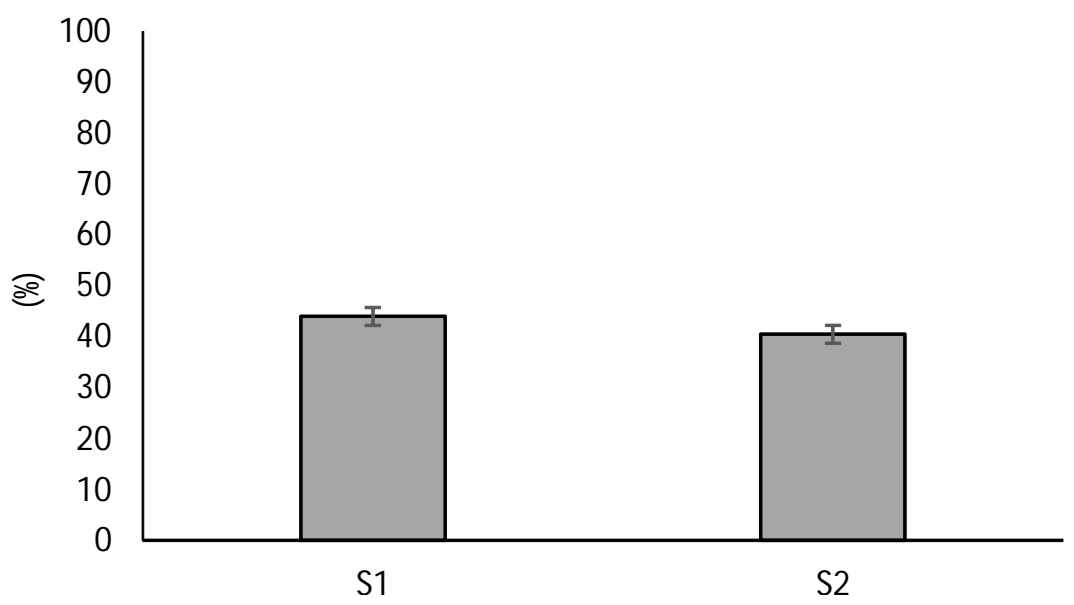

Gambar 4. Tingkat penetasan telur yang terbuahi pasca-inseminasi menggunakan jumlah spermatofor yang berbeda, $S-1=$ inseminasi dengan satu spermatofor; $\mathrm{S}-2=$ inseminasi dengan dua spermatofor

Figure 4. Hatching rate of fertil eggs produced by wild female broodstock after inseminated with different numbes of spermatophore, $S-1=$ inseminated with one spermatophore; $\mathrm{S}-2=$ inseminated with two spermatophores

masing percobaan tidak dilakukan, terjadinya pembuahan telur yang menghasilkan nauplii pada ke-2 percobaan ini dengan daya tetas yang relatif sama dengan perkawinan alami menunjukkan bahwa IB dapat menjadi alternatif dari perkawinan alami untuk menghasilkan nauplii pada udang windu. Dengan kata lain teknik IB ini dapat diaplikasikan khususnya pada induk betina yang tidak atau belum melakukan perkawinan secara alami. Selain itu, teknik IB ini dapat menjadi solusi dalam domestikasi udang windu yang kendala utamanya adalah tidak terjadinya perkawinan alami dalam wadah budidaya. Teknik IB ini dapat pula diaplikasikan pada induk alam yang sudah tidak membawa spermatofor tetapi masih melakukan rematurasi. Dengan demikian masa pematangan gonad induk dapat diperpanjang sebelum induk-induk tersebut diapkir. Dugaan terlepasnya spermatofor dari telikum induk betina menggambarkan bahwa teknik 
implantasi spermatofor pada telikum sangat penting pada keberhasilan IB sehingga teknik IB ini perlu dimodifikasi untuk mendapatkan tingkat pembuahan telur yang maksimal.

\section{KESIMPULAN}

Teknik inseminasi buatan pada udang windu alam dapat diterapkan untuk memastikan induk udang betina membawa spermatofor. Spermatofor yang diinseminasikan tidak dipengaruhi oleh sumber atau lokasi di mana induk jantan berasal, ditandai oleh tingkat penetasan telur yang relatif sama. Inseminasi buatan (IB) pada induk udang windu betina alam dengan satu spermatofor lebih efektif dibandingkan dengan dua spermatofor.

\section{UCAPAN TERIMA KASIH}

Terima kasih kami sampaikan kepada Saudara Wendy Santiajinata dan Umar, teknisi di Instalasi Pembenihan Udang Windu (IPUW), Barru yang telah membantu pelaksanaan penelitian ini. Penelitian ini merupakan kegiatan yang didanai oleh DIPA-APBN Tahun 2014.

\section{DAFTAR ACUAN}

Arce, S.M., Shaun, M., Argue, M., \& Brad, J. (2008). Artificial insemination and spawning of Pacific white shrimp Litopenaeus vannamei: implications for a selective breeding program. UJNR Technical Report, 28, 5-8.

Arnold, S.J., Coman, G.J., Burridge, C., \& Rao.M. (2012). A novel approach to evaluate the relationship between measures of male fertility and egg fertilization in Penaeus monodon. Aquaculture, 338, 181-189.

Bart, A., Choosuk, S., \& Thakur, D.P. (2006). Spermatophore cryopreservation and artificial insemination of black tiger shrimp, Penaeus monodon (Fabricus). Aquaculture research, 37, 523-528.

Chow, S. (1982). Artificial insemination using preserved spermatophore in the Palaemonid shrimp Macrobrachium rosenbergii. Bulletin of the Japanese Society of Sciientiffic Fisheries, 48(12), 1693-1695.

Claudet, P.V., Selvakumar, N., \& Natesanm, M. (2016). Effect of cryoprotectants and cooling rates on fertility potential of sperm in the giant freshwater prawn, Macrobrachium rosenbergii (de Man). Animal Reproduction Science, 171, 49-57.

Coman. G.J., \& Crocos, P.J. (2003). Effect of age on the consecutive spawning of ablated Penaeus semisulcatus broodstock. Aquaculture, 219, 445456.

Coman, G.J., Crocos, P.J., Arnold, S.J., Keys, S.J., Murphy, B., \& Preston, N.P. (2005). Growth, sur- vival and reproductive performance of domesticated Australian stocks of the giant tiger prawn, Penaeus monodon, reared in tanks and raceways. Journal of World Aquaculture Society, 36, 464-479.

Coman, G.J., Arnold, S.J., Callaghan, T.R., \& Preston, N.P. (2007). Effect of two maturation diet combinations on reproductive performance of domesticated Penaeus monodon. Aquaculture, 263, 75-83.

Jiang, S.-G., Huang, J.-H., Zhou, F.-L., Chen, X., Yang, Q.-B., Wen, W.-G., \& Ma, Z.-M. (2009). Observation of reproductive development and maturation of male Penaeus monodon reared in tidal and earthen ponds. Aquaculture, 292, 121-128.

Joseph, S., \& Diwan, A.D. (2009). Male reproductive system. In Diwan, A.D., Joseph, S., \& Ayyapan, S. (Eds.). Physiology of reproduction, breeding and culture of tiger shrimp Penaeus monodon (Fabricus). ( $p$. 39-70). Narendera Publishing House, Delhi110006. India.

Hoa, N.D. (2009). Domestication of black tiger shrimp (Penaeus monodon) in recirculation systems in Vietnam. PhD Thesis. Ghent University. Belgium, 183p.

Hoang, T., Lee, S.Y., Keenan, C.P., \& Marsden, G.E. (2002). Effects of age, size, and light intensity on spawning performance of pond-reared Penaeus merguiensis. Aquaculture, 212, 373-382.

Laining, A., Usman, \& Rachman Syah. (2014). The use of seaworm meal in maturation diet as partial substitution of fresh-diet for pond reared tiger shrimp broodstock, Penaeus monodon. Indonesian Aquaculture Journal, 9(2), 123-132.

Laining, A., Lante, S., \& Usman. (2015). Induksi pematangan gonad dan peningkatan tingkat pembuahan telur induk udang windu, Penaeus monodon melalui rangsangan hormon tanpa ablasi mata. J. Ris. Akuakultur, 10(1), 61-68.

Lante, S. (1997). Studi pendahuluan IB pada induk udang windu (Penaeus monodon Fab.) asal tambak. Prosiding II Seminar Nasional Biology XV, Konservasi dan Pendayagunaan Sumber Daya Alam Hayati di Indonesia yang Berwawasan Lingkungan. Perhimpunan Biologi Indonesia Cabang Lampung. Universitas Lampung. Lampung, hlm. 712-716.

Lante, S., Laining, A., \& Parenrengi, A. (2014). Performa reproduksi udang windu (Penaeus monodon Fab.) jantan alam dan domestikasi tambak. Prosiding Forum Inovasi Teknologi Akuakultur, hlm. 693-700.

Memon, A.J., Talpur, A.D., Khan, M.I., Fariddudin, M.O., Safiah, J., Abol-Munafi, A.B., \& Ikhwanuddin, M. (2012). Optimization of spermatophores cryopreservation protocol of Banana shrimp (Penaeus merguinsis) (de Man, 1888). Journal of Animal and Veterinary Advances, 11, 1688-1704. 
Misamore, M., \& Browdy, C.L. (1997). Evaluating hybridization potential between Penaeus setiferus and Penaeus vannamei through natural mating, artificial insemination and in vitro fertilization. Aquaculture, 150, 1-10.

Moria. S.B., Haryanti, Sugama, K., \& Permana, I G.N. (2002). Variasi genetika induk udang windu, P. monodon melalui analisa RAPD (Random Amplification Polymorphism DNA). Jurnal IImu-ilmu Perairan dan Perikanan Indonesia, IX(1), 29-33.

Mylonas, C.C., Fostier, A., \& Zanuy, S. (2010). Broodstock management and hormonal manipulations of fish reproduction. General and Comparative Endocrinology, 165, 516-534.

Peixoto, S., Cavalli, R.0., Krummenauer, D., Wasielesky, W., \& D'Incao, F. (2004). Influence of artificial insemination on the reproductive performance of Farfantepenaues paulensis in conventional and unisex maturation systems. Aquaculture, 230, 197-204.
Perez-Velazquez, M., Bray, W.A., Lawrence, A.L., Gatlin III, D.M., \& Gonzalez-Felix, M.L. (2001). Effect of temperature on sperm quality of captive Litopenaeus vannamei broodstock. Aquaculture, 198, 209-218.

Sandifer, P.A., Lawrence, A.L., Harris, S.G., Chamberlain, G.W., Stokes, A.D., \& Bray, W.A. (1984). Electrical stimulation of spermatophore expulsion in marine shrimp. Aquaculture, 41, 181-187.

World Review SOFIA-FAO. (2014). World review of fisheries and aquaculture. Rome. Italy, $96 \mathrm{pp}$.

Wouters, R., Zambrano, B., Espin, M., Calderol, J., Lavens, P., \& Sorgeloos, P. (2002). Experimental broodstock diets as partial fresh food substitutes in white shrimp Liptopenaeus vannamei B. Aquaculture Nutrition, 8, 249-256.

Yano, I., Ruchimat, T., Sutarmat, T., Tridjoko., Lante, S., Hutapea, J.H., Makinouchi, S., \& Kuma, C. (1996). Effects of vitamin $\mathrm{E}$ on maturation and spawning in giant tiger prawn, Penaeus monodon. Suisanzoshoku, 44(4), 497-502. 